\title{
MOUNTAIN AND MOLEHILL? CORNELIUS TACITUS AND QUINTUS CURTIUS*
}

It has long been recognized that there are many verbal similarities between Tacitus and Quintus Curtius Rufus, the Roman historian of Alexander the Great. As early as 1887, Friedrich Walter listed some 600 instances, ranging from the remarkable to the commonplace, ${ }^{1}$ and the key passages have been episodically rediscovered over the intervening years. ${ }^{2}$ In Walter's view the resemblances could not be fortuitous, nor could Tacitus be borrowing from Curtius. The greatest historian of Rome would hardly have taken terminology from a work that is (and was) wholly obscure. This is much the same as Simon Hornblower's view, recently expressed, of the intertextual relationship between Thucydides and the Old Oligarch: 'We should not easily accept that a minor work with no immediate future in front of it should have influenced the greatest work of its age; that the molehill should have moved the mountain.' ${ }^{3}$ For Hornblower, the Old Oligarch was echoing and responding to the greater writer. Walter, on the other hand, refused to accept that Curtius drew on Tacitus, because of his conviction, then universal, that Curtius' was the earlier work. The only conclusion, then, was that both writers drew independently upon a common rhetorical stock, derived predominantly from Sallust and Livy.

There are a number of doubtful postulates here. Are we to assume that Curtius' work was obscure simply because there is no explicit reference to it in our extant body of sources? Hardly so. The body of sources is far from exhaustive. After the Julio-Claudian period, our knowledge of Roman historiography is pathetically small. Quintilian's famous review of Roman historians goes no further than Servilius Nonianus; he betrays no knowledge of the extensive historical works of the Elder Pliny or, for that matter, of Fabius Rusticus. ${ }^{4}$ Rusticus is an interesting case. Though he was

* I am grateful for constructive criticism from many sources, in particular from Liz Baynham, Jane Bellemore, and John Yardley, and from the journal's referees. Whatever imperfections remain are my own responsibility.

${ }^{1}$ F. Walter, Studien zu Tacitus und Curtius, Programm des Kgl. Wilhelms-Gymnasiums in München für das Studienjahr 1886/87 (Munich, 1887), esp. 7-11. This is a monument of diligence and erudition, and I doubt whether the compendium could be enlarged. However, what Walter was unable to do was to determine the uniqueness of the vocabulary and the appropriateness of the allusions. Together, these two factors may establish the temporal and literary relationship between Curtius and Tacitus.

2 In particular, L. Alfonsi, 'Nota Tacitiana', Aevum 41 (1967), 154-5; S. Borzsák, 'Alexander d. Gr. als Muster taciteischen Heldendarstellung', Gymnasium 89 (1982), 37-56; A. A. Lund, 'Lexikalische und kritische Bemerkungen zu Tacitus und Curtius Rufus', Gymnasium 94 (1987), 50-6; 'Neues zu Curtius 3,5,1. 3,10,5. 4,10,3', Gymnasium 94 (1987), 438-41. See also the comprehensive bibliography by Holger Koch, Hundert Jahre Curtius-Forschung (1899-1999). Eine Arbeitsbibliographie, Subsidia Classica 4 (St Katharinen, 2000).

${ }^{3}$ Simon Hornblower, 'The Old Oligarch (Pseudo-Xenophon's Athenaion Politeia) and Thucydides. A fourth-century date for the Old Oligarch?', in P. Flensted-Jensen, T. H. Nielsen, L. Rubinstein (edd.), Polis \& Politics. Studies in Ancient Greek History (Copenhagen, 2000), 363-84. The quotation comes at 371.

${ }^{4}$ Quint. 10.1.102-3. He goes on (at 104) to allude to an unnamed historian who is the glory of his age, and he has been thought to be referring to Fabius (R. Syme, Tacitus [Oxford, 1958], 179, n. 8; assumed without question in R. M. Ogilvie and I. Richmond, Cornelii Taciti De Vita 
a friend and associate of Seneca, he and his historical work are only attested by Tacitus, and Tacitus himself concedes that he was the most eloquent of recent historians. ${ }^{5}$ This is a verdict to be respected, and Tacitus acted accordingly, opting for Fabius as a source for the Neronian period. ${ }^{6} \mathrm{Had}$ he not used and cited him, Fabius' work and the man himself would be unknown. Now, in Curtius' case there is no subsequent Latin history of Alexander, no writer who might have identified him by name as a source, and it is not surprising that he is not named in the extant tradition. That does not, of course, mean that he had no effect upon it. Sallust and Livy, for instance, are echoed repeatedly out of context and without acknowledgement in later rhetoric, and I shall argue that the same applies to Curtius.

Next, the mountain and the molehill. Are we to assume that a greater writer could not draw upon a lesser one? Surely the context is decisive. It is, I would agree, unlikely that Tacitus (or Thucydides) would simply borrow rhetorical phraseology from an earlier work. However, if Curtius were indeed highly popular in Tacitus' day, the great historian might play upon his readers' familiarity with him, evoking the more striking expressions to improve upon them. There is a more subtle procedure. The echoes could amount to a sub-text; the context in Curtius might add piquant and sophisticated resonances, extending or sometimes undermining Tacitus' overt meaning. It has long been accepted that Tacitus engages in a dialogue with Livy and Sallust, ${ }^{7}$ and the same may be true - to a limited degree - with Curtius. Of course, the reverse might apply. Curtius might be imitating Tacitus, offering him the sincerest form of flattery, but I would argue that the echoes in Tacitus give a much sharper rhetorical effect. ${ }^{8}$ What would be haphazard in Curtius is high literary artistry in Tacitus. Time after time the evocation of Alexander through Curtius gives a sharp implicit comment on the subject matter which does not hold in the reverse direction.

There is another fundamental issue. There was a huge body of literary rhetoric circulating in the Roman world during the early empire, and only a small fraction of it is extant. In any individual instance of a rhetorical echo there is always the possibility that the two authors are drawing independently from a common stock of material. That is the argument behind, say, Friedrich Wilhelm's study of the relationship between Curtius and the younger Seneca. ${ }^{9}$ Wilhelm accumulates parallels from extant literature, and comes to the conclusion that there can be no direct relationship between the two authors. That is probably largely correct in the case of Curtius and Seneca. However, what Wilhelm did not establish (and was in no position to establish) was the unique correlation. If the echo is unique, not paralleled elsewhere in the extant literature, then there is a fair chance that one author is borrowing from another. ${ }^{10}$ For

Agricolae [Oxford, 1967], 167). Vipstanus Messala could also be considered, given Tacitus' strongly expressed commendation (Hist.3.9; cf. 3.25, 28; 4.42.1).

5 Tac. Agr. 10.3: Livius veterum Fabius Rusticus recentium eloquentissimi.

6 Tac. Ann. 13.20.2; 14.2.2; 15.61.3. There are no other named citations.

7 See particularly Syme (n. 4), 728-34, and for discussion of some interesting parallels, A. J. Woodman, Tacitus Reviewed (Oxford, 1998), 231-6.

${ }^{8}$ So recently Rhiannon Ash, 'Warped intertextualities: Naevius and Sallust at Tacitus Histories 2.12.2', HISTOS 1 (1997): 'If the echo fails to add interesting layers of meaning to the text under consideration, then there is limited mileage in asserting a connection between two passages in different authors'.

${ }^{9}$ F. Wilhelm, Curtius und der jüngere Seneca (Paderborn, 1928). Walter (n. 1) uses essentially the same method with Curtius and Tacitus.

${ }^{10}$ For the principle, see Stephen Hinds, Allusion and Intertext. Dynamics of Appropriation in Roman Poetry (Cambridge, 1998), 25: 'a rare word or expression in one passage picks up a corresponding rarity in a predecessor passage, serving thus as an unequivocal marker of allusion'. 
instance, Wilhelm notes that Seneca (Ep. Mor. 59.12) introduces an account of Alexander's wounding at Massaga with a striking contextual phrase: Alexander was devastating peoples so remote as to be unfamiliar even to their neighbours (gentes ne finitimis quidem satis notas). ${ }^{11}$ The same phraseology occurs twice in Curtius, in different contexts. ${ }^{12}$ It does not recur elsewhere in extant literature. There are numerous explanations possible. It might be a coincidence, the two authors independently using a tag current in the rhetorical schools, which happens to be unattested in the extant literature. However, if there are other unique correlations, then the probability of a direct relationship increases exponentially with each such correlation. The multiplicity of unique attestations guarantees the dependency, and the appropriateness of the allusions determines who is dependent on whom. In the case of Curtius and Tacitus, we have the required multiplicity, and with each instance it is Tacitus' narrative that gains in sharpness with the literary echo. Alexander is the universal comparandum, and can serve as a repeated subtext to the narrative.

Let me begin with a relatively simple case. Tacitus (Ann. 13.17.1) notes that people were inclined to condone the murder of Britannicus, 'bearing in mind the ancient quarrels of brothers and the impossibility of sharing kingship' (antiquas fratrum discordias et insociabile regnum aestimantes). The wording is highly allusive. The immediate reference is to the quarrel between Romulus and Remus, and there could be some reflection of the murder of Tiberius Gemellus at the hands of Caligula. Then also, according to Philo (Leg. 9.68), it was stated that sovereignty could not be shared

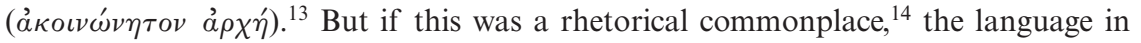
which it is expressed is hardly run of the mill. Insociabilis is used a handful of times in extant Latin literature, and only once (outside Tacitus) is it paired with regnum. The pairing occurs in one of the most famous passages of Curtius (10.9.1), where he looks ahead to the civil wars after Alexander's death. They were brought on by fate, for kingship cannot be shared (nam et insociabile est regnum) and there were several contenders. This parallel clearly adds force to the comment that Tacitus puts in the mouth of contemporaries of the death of Britannicus; Rome risked the same danger as Alexander's empire. It was not simply that brothers might quarrel over power; ${ }^{15}$ the

The method is used in a new study by J. C. Yardley, Justin and Pompeius Trogus. A Study of the Language of Justin's 'Epitome' of Trogus, Phoenix Suppl. 41 (Toronto, 2003). See also the formative article by Ziva Ben-Porat, 'The politics of literary allusion', PTL 1 (1976), 105-28, with her concluding remarks on the cumulative strength of literary markers.

${ }_{11}$ Wilhelm (n. 9), 61-5, adducing Sen. Ep. Mor. 59.12. Curtius 8.10.27-9 gives exactly the same story with the same details, but does not have the rhetorical introduction. Both accounts reflect a common source (so Wilhelm), but it is possible that Curtius was aware of Seneca's treatment and reused his introductory flourish in other contexts. The alternatives are random borrowing by Seneca or sheer coincidence.

${ }^{12}$ Curt. 7.3.5: the people in Parapamisadae (nationem ne finitimis quidem satis notas); Curt. 4.12.9: peoples in Darius' grand army (gentes ne sociis quidem satis notas`).

${ }^{13}$ Observed in Furneaux' commentary ad loc. L. Alfonsi, 'Nota Tacitiana', Aevum 41 (1967), 154-5, argues that Curtius is more pertinent to the context.

${ }^{14} \mathrm{~J}$. E. Atkinson gives a number of parallels in his Mondadori edition (see also his Commentary on Q. Curtius Rufus' Historiae Alexandri Magni Books 3 and 4 [Amsterdam and Uithoorn, 1980], 26-7). The thought goes back to Ennius (Cic. Off. 1.26 = Ennius Trag. 411-12), but the striking wording is not paralleled. The closest is Livy 1.14.3: ob infidam societatem regni (referring to Romulus and Tatius), which lacks the force of Curtius and Tacitus.

${ }^{15}$ This is practically a topos, as Tacitus admits. In an earlier passage Piso wrongly assumed that there would be animosity between Germanicus and Drusus (Tac. Ann. 3.8.1, with the commentary of Woodman and Martin). 
quarrel in an empire might lead to internecine war and dissolution. ${ }^{16}$ The echo gives the phraseology a much more sinister undertone, which strengthens the message of the commentators. From their perspective, what was at stake was not a court quarrel but the very integrity of the empire. In that context, the evocation of the wars of the Successors has a strong impact. Conversely an allusion in Curtius to the murder of Britannicus would be bathetic in the context of the death of Alexander. It is Tacitus' narrative that gains in effect from the literary allusion.

This evident echo helps define another. In his celebrated introduction to the Historiae (1.11.3), Tacitus defines the consulate of Galba and Vinius as the last year for Galba and almost terminal for the state (annum sibi ultimum, rei publicae prope supremam). This is remarkably similar to Curtius' reference (10.9.3) to the metaphorical night of the state which preceded the elevation of the current princeps (noctis quam paene supremam habuimus). There are other parallels, notably Vergil's allusions to the last night of Troy, ${ }^{17}$ and Livy's rhetorical invocation of the Gallic attack on the Capitol, the night which almost saw the end of all things Roman (noctis illius quae paene ultima atque aeterna nomini Romano fuerit). ${ }^{18}$ Livy may well have independently influenced both the later historians. However, there is a strong verbal link between Curtius and Tacitus. The qualification of the adjective (paene/prope supremus) does not occur elsewhere in literary Latin, ${ }^{19}$ and the unique correlation increases the probability that Tacitus is alluding to Curtius. And once again the context of the allusion adds significantly to its rhetorical effect. Tacitus' wording does not merely evoke the crisis of the Roman state that inspired Curtius. It suggests the parallel of Alexander's empire and its dismemberment at the hands of competing marshals, which was all too apposite in the context of the wars of A.D. 69. There is, however, no explicit comparison. Tacitus, it seems, can rely on his readers to respond to the verbal stimulation and adduce the context of Alexander history.

The same may be said of a remarkable passage in the Agricola (2.3). Tacitus gives us a highly wrought description of Domitian's suppression of dissent, and concludes: 'we have given a formidable demonstration of submission' (dedimus profecto grande patientiae documentum). Again, the language is forceful and almost unique; ${ }^{20}$ again, the parallel is in Curtius. ${ }^{21}$ The context is the so-called 'mutiny' of Opis. There Alexander responded to the contumacy of his troops by summarily executing thirteen of them. ${ }^{22}$ That immediately put a stop to the unrest, as the troops accepted the

16 The converse, that the danger of civil war necessitated one man rule, is a recurrent theme: Tac. Ann. 1.9.4 (non aliud discordantis patriae remedium fuisse quam $<u t>$ ab uno regeretur); Hist. 1.16.1; cf. Lactant. Div. inst. 7.15.14 = Seneca F 1 (Peter 2.92).

17 Aen. 5.190 (sorte suprema); 6.502-3, 513 (nox suprema).

18 Livy 6.17.4. The parallel has often been noted; cf. Oakley's commentary ad loc.: 'the best parallel... is Curt. x. 9. 3... also analogous is Tac. hist. i. 11. 3'. C. S. Kraus in her Cambridge commentary draws attention to Plin. Ep. 6.20.15. aeternamque illam et novissimam noctem mundo interpretabantur. The terminology may well echo Livy, but the reference is to an actual night (after the eruption of Vesuvius), which was in fact thought to be the end of the world (cf. Dio 66.23.5).

19 It is found only in the late grammarian Terentianus Maurus (De metr. $1870=$ H. Keil, Grammatici Latini 6.475). At Ennius Var. 40 paene qualifies the entire surrounding phrase not simply the adjective.

${ }^{20}$ Sen. Prov. 3.9 describes Regulus as documentum fidei, documentum patientiae. This lacks the rhetorical shaping of Curtius and Tacitus, and the context is much less appropriate.

${ }^{21}$ The verbal parallel has often been noted. Cf. Lund (n. 2), 50-1: 'Der Vergleich zwischen princeps und rex liegt auf der Hand'.

${ }^{22}$ Curt. 10.2.30. The facts are well attested. Cf. Arr. 7.8.3; Just. 12.11.8-9; Diod. 17.109.2; 
executions and sued for their king's forgiveness (10.3.4): 'they provided an outstanding example of submission; so far did they fail to be fired to anger by the punishment of their comrades' (singulare certe ediderunt patientiae exemplum, adeoque non sunt incensi supplicio commilitonum). This exactly mirrors Tacitus' language. The shaping is the same, the wording subtly varied. ${ }^{23}$ It also mirrors the context. The Roman world, and the Senate in particular, fails to react to the executions and expulsions ordered by Domitian, just as the Macedonians countenance the disciplinary executions. But the parallel goes further. At Opis Alexander was at his most fearsome, his legendary irascibility erupting tempestuously, ${ }^{24}$ and Curtius describes the violent action in a few starkly memorable lines: 'then he leaped down from the tribunal with clenched teeth, and drove into the middle of the gathering of armed troops. He had marked out the men who had been fiercest in their abuse and arrested them with his own hand one by one without their daring to resist.' Tacitus evokes that celebrated scene, and it allows him to insinuate that Domitian was as intimidating as Alexander in his most elemental passion. The Senate (including Tacitus himself) may have plumbed the depths of servility and been cowed to silence, but the terror inspired by the emperor was such that there was no alternative. It is not implied that Domitian was another Alexander, rather that he had to excess one of Alexander's worst traits, his iracundia. ${ }^{25}$ The close echo of Curtius provides the trigger for the reader to superimpose the context of Opis and view Domitian's behaviour as the ultimate in intimidation. Under those conditions, who could blame Tacitus and his contemporaries for their patientia? Once more the context in Curtius adds point to the echo in Tacitus. On the other hand, if Curtius is borrowing from Tacitus, then Alexander is implicitly compared with Domitian. The unheroic recluse of the Agricola and Pliny's Panegyric would become a model for the world conqueror. That would be anticlimactic indeed.

The most striking accumulation of echoes comes in the paired speeches for Agricola and the Caledonian chieftain Calgacus. Here the model appears to be Curtius' speeches for Alexander and Darius on the eve of Gaugamela, and Walter went so far as to list the relevant passages in parallel columns. ${ }^{26}$ As we should expect, there is considerable subtlety in the allusions. Agricola takes up Curtius' striking phrase that the enemy has been rooted out of its lair (ex latebris suis erutos) with minimal variation of the wording (e latebris suis extrusi) ${ }^{27}$ It evokes Alexander's proud self-confidence and implicitly compares the Caledonian hordes with the doomed army of Darius.

Plut. Alex. 71.4. Justin also draws attention to the troops' patientia moriendi, which was doubtless a feature of the rhetorical tradition. If it was a topos, it will have attuned the audience's ears to Tacitus' allusion

${ }^{23}$ There is no parallel elsewhere in Latin for the exact shaping of the sentence. Singulare exemplum is rare enough (apart from Curtius only in Ps. Quint. Decl. 6.9 and Vell. 2.100.4), while Tacitus is alone in using the combination grande documentum. He imitates the shape of Curtius' sentence with slightly more exotic terminology. This embodies two of the 'philological criteria' (similarity in the choice of words, position of words in the line) which are listed by K. Morgan, Ovid's Art of Imitation: Propertius in the Amores (Leiden, 1977), 3, quoted by Hinds (n. 10), 26.

24 So too Arr. 7.8.3, 11.1, drawing attention to Alexander's ó $\xi \dot{\tau} \tau \eta s$.

${ }^{25}$ Livy 9.18.5: trux ac praefervida ira (a trait agreed upon in the literary tradition). Cf. Curt. 3.12.19; 4.2.5, 4.17; 4.6.29 (ira vertit in rabiem); 6.5.19; 8.1.34, 43; 10.4.2. On Curtius' attempted mitigation of Alexander's iracundia (10.5.33-4), see below, pp. 559-560.

${ }_{26}$ Tac. Agr. 30-4; Curt. 4.14.1-26. Cf. Walter (n. 1), 8, commenting 'Es wird Niemand diese Übereinstimmungen für zufällig erklären'.

27 Tac. Agr. 33.4; Curt. 4.14.4. 
The enemy has been tracked down, forced to fight because they can flee no further. Alexander and Agricola mirror each other with strikingly similar terminology. ${ }^{28}$ They do so again in other contexts. Curtius has Alexander remind his men of the distance they have travelled and the multitude of mountains and rivers at their backs, as does Agricola, who makes it explicit that the distance his men have covered and the natural obstacles they have overcome will be lethal in defeat (periculosissima quae hodie prosperrima sunt) ${ }^{29}$ However, there is a significant difference. Alexander does not enlarge on the perils of retreat. He says that would only have been necessary if they had been men of a different stamp, not the brave warriors that they were (4.14.7). By contrast, Agricola dwells on the dangers, building up to a climax in which he discounts all thoughts of retreat. His men are not the counterparts of Alexander's troops, but despite that, Agricola secures the victory that takes him to the end of the earth. It will not be devoid of glory, he claims (Agr. 33.6), to fall at the very limit of the earth and nature itself - again recalling Curtius' Alexander, who claimed to be near the end of the earth, which he intended to leave and open up another nature and another world (haud procul absum fine mundi, quem egressus aliam naturam, alium orbem aperire mihi statui) ${ }^{30}$

The limits of nature are an important theme. In the Agricola it is repeatedly evoked in the narrative of the last campaigning year. ${ }^{31}$ Before the engagement at Mons Graupius, Agricola's troops, flushed with confidence, boast that nothing is impassable for their courage (nihil virtuti suae invium) and that they would finally discover the boundary of Britain (Agr. 27.1). The thought is commonplace enough, but the wording is not. The coupling nihil invium recurs once in Latin literature, and again it is in Curtius. His Alexander concedes that it would be hard to campaign against the Indians of the Ganges valley, men who were 'removed to virtually the ultimate boundary of humanity' (relegatos in ultimum paene rerum humanarum . . terminum); nonetheless, his passion for glory was such that he felt that nothing was impassable or remote (nihil invium, nihil remotum) ${ }^{32}$ This is Alexander at his most unbridled, his temeritas unsurpassable, and Tacitus' echo of the passage has considerable ironical force. ${ }^{33}$ Agricola's troops use the language of Alexander, but Tacitus is careful to emphasize that these were the men who had recently put discretion before valour and

28 Curt. 4.14.2: reprehensos ex fuga Persas pugnaturos quia fugere non possent. Tac. Agr. 34.3: quos quod tandem invenistis, non restiterunt, sed deprehensi sunt. A few sentences earlier (34.1) the Caledonians are contemptuously characterized as ceterorum Britannorum fugacissimi.

29 Tac. Agr. 33.5. The previous words, superasse tantum itineris, evasisse silvas, transisse aestuaria, echo Alexander at Curt. 4.14.7: tot terrarum spatia emensis, tot amnibus montibusque post tergum obiectis. As Ogilvie and Richmond observe, the ultimate inspiration is Livy 21.43.9.

${ }^{30}$ Curt. 9.6.20. The context is a speech in which Alexander boasts that he has made the choice of Achilles, death and glory in preference to old age and obscurity (for the topos compare Arr. 5.26.6). Agricola has made the same decision: death is preferable to defeat.

${ }^{31}$ See most recently Katherine Clarke, 'An island nation: re-reading Tacitus' Agricola', JRS 91 (2001), 94-112, esp. 100-4.

32 Curt 9.2.9. Arrian 5.25.2 agrees that the reports of the peoples beyond the Hyphasis stimulated ( $\pi \alpha \rho \omega^{\prime} \xi v \nu \epsilon \nu$ '́s $\left.\epsilon^{\prime} \pi \imath v \mu \iota^{\prime} \alpha \nu\right)$ Alexander to advance further, and the motif of world empire is explicitly aired in the speech that follows (cf. 5.26.2 for the limiting factor of the circumambient ocean).

${ }^{33}$ Curtius also combines the motifs of greed and insatiability (avaritia gloriae et insatiabilis cupido famae), which recurs in the speech of the Scythian elder (Curt. 7.8.19-20), echoed by Tacitus' Calgacus (Agr. 30.4; see below, p. 558). This is admittedly a topos (cf. Sen. Ep. Mor. 94.43), but the unique echo of nihil invium strengthens the possibility that Tacitus was influenced directly by Curtius. 
pressed for a retreat from Caledonia. ${ }^{34}$ They are emotionally volatile, reacting extravagantly to a single victory, achieved by the strategy of Agricola. Here the invocation of Alexander highlights the unreliability of the troops, who have pretensions beyond their abilities. It is only Agricola's generalship that takes them to the furthest bounds of Britain. ${ }^{35}$ Like Alexander, he goes as far as the ocean, and his fleet encounters the sluggish, heavy waters off the north of Scotland, a description that recalls Pytheas' fabulous account of the northern extremity of the earth, where land and sea coalesce into a sort of sludge with the consistency of a jellyfish. ${ }^{36}$ It was further proof that Agricola had gone as far as it was physically possible for a human; even Pytheas' Thule, at the rim of the earth, had come under observation. ${ }^{37}$ In that respect he could have outstripped Alexander, who did reach the ocean off southern Sind, but notoriously failed to penetrate to its eastern reaches. His speech at Mons Graupius accordingly has colouring that recalls Alexander.

Agricola, then, is a curious blend, gaining military successes which rival those of Alexander but achieving them by sober caution. His counterpart, Calgacus, is equally complex. In some respects he echoes Curtius' Darius. Like Darius at Gaugamela, he refers to the moral effect of the women and children present at the battle site, but the emphasis is different; in Tacitus they fire the courage of their warriors while in Curtius they are to be kept out of enemy hands. ${ }^{38}$ This might be chance coincidence, as probably is the invocation of salus and gloria as contrasting motives for engagement. Both authors could there be echoing Sallust's striking observation that the Romans had always fought with the Gauls for deliverance rather than glory. ${ }^{39}$ But there is a more apposite parallel than Darius. At the first rhetorical climax of his speech ( $A g r$. 30.5) Calgacus indicts the Romans as universal brigands: 'robbers of the world, they rifle the deep, after the land is exhausted by their global devastation. If the enemy is rich, they are rapacious, if poor, their aim is aggrandizement. Neither the east nor the west would glut their appetite.' This is not an unfamiliar motif. The gist of it is found in the famous letter of Mithridates which was a showpiece of Trogus' Philippic Histories: the Romans have 'an insatiable thirst for blood and a ravenous hunger for power and riches'. ${ }^{40}$ But the thought here is different. For Calgacus the dominant characteristic of the Romans is not so much their greed as their obsession to dominate. even when their prospective subjects are paupers. A far closer parallel comes in

${ }^{34}$ Agr. 27.2: atque illi modo cauti ac sapientes prompti post eventum ac magniloqui erant. Cf. 25.3: ignavi specie prudentium.

35 Compare Agr. 37.4, where Agricola's foresight prevents losses caused by his troops' overconfidence (per nimiam fiduciam). He gains results comparable to the victories of Alexander without Alexander's besetting temeritas.

${ }^{36}$ Agr. 10.5: pigrum et grave... profunda moles continui maris tardius impellitur. For Pytheas' description see Strab. 2.4.1 (104), with J. S. Romm, The Edges of the Earth in Ancient Thought (Princeton, 1992), 22-3, 148-9 and the recent discussion of Katherine Clarke (n. 31), 97-8. I do not think (contra Clarke) that it parallels Scylax's account of the island of Cerne in the Atlantic; in that context, the obstacles to navigation are the familiar ones of shallows, mud, and seaweed, not a totally new phenomenon. There the laws of physics definitely do apply. It is the far north that boasts a uniquely strange substance.

37 Agr. 10.4: dispecta est et Thule. Tacitus adds that Agricola had no mandate beyond the Orkneys (quia hactenus iussum) and winter was approaching. Hence he did not set foot on Thule, showing a prudence which Alexander would never have entertained.

${ }^{38}$ Tac. Agr. 32.2: nullae Romanos coniuges accendunt. Contrast Curt. 4.14.22.

39 Sall. BJ 114.2 (see also 94.5): cum Gallis pro salute, non pro gloria certare. Cf. Curt. 4.14.9: iam non de gloria, sed de salute... pugnandum est; Tac. Agr. 31.4: sumite animum, tam quibus salus quam quibus gloria carissima est. Walter (n. 1), 8 also adduces Livy 21.41.13 and Just. 28.4.2.

40 Just. 38.6.8, directly reproduced from Trogus; cf. Sallust Hist. 4.67.5, 22. 
Curtius, where an anonymous Saca elder confronts Alexander and reads him a lesson in moderation. ${ }^{41}$ The contrast of east and west is there in a striking analogy: if Alexander's physical stature matched his ambition he would grasp the east with one hand the west with the other (7.8.12). Like the Romans, he is the universal brigand (omnium gentium quos adisti latro es), and like the Romans, he is insatiable, even for the herds of the Saca nomads. ${ }^{42}$ Greedy and insatiable, Alexander parallels the Romansor perhaps the emperor under whose auspices Agricola and his troops were fighting. He is indicted by a noble of the nomadic peoples just south of the limits of civilization, whom Alexander would defeat and pursue beyond the boundary markers established by Dionysus himself. ${ }^{43}$ The parallel with Calgacus could not be clearer. He is faced by an aggressive insatiable power which he denounces, but in the long run resistance is futile. The Sacae were roundly defeated, and the same was the case with Calgacus. The echo of Curtius heightens the pathos, suggesting that the Caledonians were doomed, confronted by a new Alexander.

There is another facet to the parallel. Curtius insists that the Sacae did not lack culture, and considers it worth recording what his sources reported of the elder's address. ${ }^{44}$ However, he considers that it lacks sophistication for contemporary tastes (abhorrent forsitan moribus nostris), and renders the content in short, simple, uncoordinated sentences, sprinkled with homely similes. Tacitus' Calgacus, however, is a very different orator. He gives a brilliant display piece, replete with rhetorical technique, and for a recent writer he expresses himself in better Latin than the Romans themselves. ${ }^{45}$ It is hard to believe that Tacitus conceived Calgacus expressing himself in Latin rather than Celtic, but he has given him a longer, richer, and more daring piece of rhetoric than he has Agricola. He uses themes from the address of the Sacan elder, but dresses them in far more exalted language. This is how the elder should have expressed himself to make the most of his material. Tacitus, then, improves on Curtius, and he uses Calgacus as his mouthpiece. A particularly good example is the famous aphorism: 'when they create a desert they call it peace' (ubi solitudinem faciunt, pacem appellant: Agr. 30.5). Tacitus was clearly proud of the expression, for he recycles it in a simplified form in the Historiae, again in the mouth of an enemy of Rome, the Batavian Civilis. ${ }^{46}$ However, it is difficult to find exact parallels in earlier literature. Livy approaches it when he describes Tarquinius Priscus as intent upon inflicting upon the curia the desolation he had wrought in his own home, a passage that Pliny develops in his portrait of Domitian. ${ }^{47}$ But Curtius is far closer when he has Alexander reproach his marshals for their caution: 'you are late in the day to start putting numbers on the armies of your enemies, after you have made a desert in Asia by conquering' (postquam

${ }^{41}$ On this exchange see now L. Ballesteros-Pastor, 'Le Discours du Scythe à Alexandre le Grand', RhM 146 (2003), 23-37, offering a string of literary parallels.

${ }^{42}$ Curt. 7.8.19: iam etiam ad pecora nostra avaras et insatiabiles manus porrigite.

${ }^{43}$ Curt. 7.9.15: transierant iam Liberi patris terminos. Cf. Metz Epit. 12, with A. B. Bosworth, 'Alexander, Euripides and Dionysos: the motivation for Apotheosis', in R. W. Wallace and E. M. Harris (edd.), Transitions to Empire (Norman, 1996), 140-66, esp. 146-9.

${ }^{44}$ Curt. 7.8.11, a clear echo of Hdt. 2.123. Cf. E. J. Baynham, Alexander the Great. The Unique History of Quintus Curtius (Ann Arbor, 1998), 86-90.

${ }^{45}$ Clarke (n. 36), 105-9: 'We thus have the paradoxical scenario in which Calgacus... is more skilled in the art of speaking Latin than are the Romans themselves... Britain in its pristine state, as represented by Calgacus at Mons Graupius, is the location of true eloquentia and virtus.'

${ }^{46}$ Hist. 4.17: servitutem falso pacem vocarent.

${ }^{47}$ Livy 1.53.6: ut quam in curia solitudinem fecerit domi quoque faciat; Pliny Pan. 48.5: nec umquam ex solitudine sua prodeuntem, nisi ut solitudinem faceret. 
solitudinem in Asia vincendo fecistis). ${ }^{48}$ This was very probably the model for Tacitus, which he sharpens with the ironic contrast of peace (which of course was the result of conquest) and desolation. ${ }^{49}$ And Calgacus again refers implicitly to Alexander; his terminology suggests that the Romans have all the destructive force of the Macedonians. Despite all his optimistic rhetoric, the Caledonian leaves his readers with the impression that he and his people are doomed.

The campaigns of Agricola were a perfect context for the invocation of Alexander. There was a major victory against an uncivilized but valiant people on the northern fringe of the populated world, and in Rome there was a malevolent autocrat who could be compared and contrasted with the imperious Macedonian. There is another, more famous parallel in the Annals. There Tacitus gives a brilliant picture of the death of Germanicus and alleges that when the prince's body was cremated there were people who compared him favourably with Alexander. Unlike the Macedonian, he was gracious to his friends, moderate in his pleasures, and content with a single marriage with defined progeny; he was no less a general, if lacking Alexander's temeritas, and if he had enjoyed Alexander's total freedom of action he would have equalled his military glory, while he had outstripped him in clemency, temperance, and the other moral qualities. ${ }^{50}$ Now, Curtius gives a similar appreciation of Alexander, which he presents as his own verdict. He stresses Alexander's good qualities (physical and mental fortitude, liberality, and sexual restraint), but concedes that there were faults which advancing age might mitigate, the lust for glory and divine honours, irascibility, and an excessive liking for wine. ${ }^{51}$ Both Curtius and Tacitus rehearse standard criticisms of Alexander, commonplaces of the schools, and it might be thought that the two texts are unconnected. However, I think a case can be made that Tacitus knew Curtius' necrology, and subjected it to the same rhetorical transformation that we have seen at work in the Agricola.

In the first place, consider Alexander's generosity to his friends. This is repeatedly stressed by Curtius: his liberality saw him give more than people asked of the gods and he displayed generosity (benignitas) to almost all his friends (10.5.31). The qualification 'almost' (fere) is significant, ${ }^{52}$ Curtius had in mind those friends who experienced the polar opposite of benignitas: Parmenion, Philotas, Cleitus, and others. ${ }^{53}$ The grudging admission of Alexander's iracundia has the same effect. Hence what Tacitus stresses in Germanicus is not his munificence. Towards his friends he is

${ }^{48}$ Curt. 9.2.24. There is a similar sentiment at Curt. 8.8.10, where Alexander justifies his treatment of the Persian nobility by claiming that he did not come into Asia to make a desert out of half the earth (non ut funditus everterem gentes nec ut dimidia parte terrarum solitudinem facerem).

49 Walter (n. 1), 8 drew attention to $A g r$. 30.4, the equally famous aphorism: omne ignotum pro magnifico. This perhaps recalls and inverts Alexander's speech at Gaugamela, where he puns sarcastically: 'the very fact that the Persian native troops were unknown (ignoti) meant that they were contemptible (ignobiles)'. On the contrary, Calgacus implies, to be unknown makes one's discovery all the more exciting for the aggressor.

50 Tac. Ann. 2.73.1-3. For the rhetorical context see A. B. Bosworth, From Arrian to Alexander (Oxford, 1988), 152-6. The parallel between Germanicus and Alexander has often been noted (see most recently, J. A. P. Gissel, 'Germanicus as an Alexander figure', C\&M 52 [2001], 277-301), but the linguistic echoes have not to my knowledge been systematically studied.

${ }_{51}$ Curt. 10.5.26-37. He insists that Alexander's good qualities were in his nature, the bad qualities due to fortune or youth, and that would be the verdict of any fair critic (26: iuste aestimantibus).

${ }^{52}$ So Baynham (n. 44), 130: 'Curtius' use of fere... is truly a brilliant touch'.

${ }^{53}$ Curtius had made the point explicitly in an earlier digression (3.12.18-21: see the discussion in Baynham [n. 44], 125-30). There he observes that Alexander was unable to overcome his 
mitis. ${ }^{54}$ 'Kind', 'soft', 'gentle' are the appropriate synonyms and suggest the opposite of Alexander's behaviour. Whatever Germanicus did with his friends, he did not kill them, even the difficult, recalcitrant Piso, and so he can be displayed as a model of clementia. ${ }^{55}$ Tacitus' carefully chosen terminology undermines the claims Curtius makes for his hero; Alexander might have been liberal, but unlike Germanicus, he was intensely difficult to live with. The same process occurs with the motif of temperantia. For Curtius, Alexander observed moderation in immoderate passions, kept his lovemaking within the bounds of natural desire, and enjoyed only the pleasures permitted by custom. ${ }^{56}$ The wording again displays a certain awkwardness. Curtius terms the passions immodicae so that he can contrast Alexander's modus, but he concedes that he was subject to immoderate passions, just like his troops, who succumbed to the corruption of the fleshpots of Babylon. ${ }^{57}$ The subsequent qualifications are similarly evasive. We are not told what are the pleasures permitted by custom or the bounds of natural desire. But the terminology reminds us of Spitamenes, who banished his wife and spent the nights with his concubines to relieve his desire. ${ }^{58}$ Another sort of desire might have been satisfied by the eunuch Bagoas. ${ }^{59}$ At all events, Tacitus can contrast Germanicus, content with a single female sexual partner $^{60}$ and moderate in his pleasures: modicus evokes Curtius' immoderatae cupidines, but it is applied to the man. Germanicus has all the moderation that Alexander's passions lacked, and his temperantia, it may be noted, is the polar opposite of Alexander's cupido vini, which was undeniably immoderate.

Another theme that Tacitus subverts is that of Alexander's temeritas. Curtius (10.5.29) stresses the positive, the king's consistent disregard for death (mortis. . . perpetua contemptio), which is the bugbear of the rest of mankind. Here Alexander's disregard for danger is presented as a moral attribute, the ultimate in bravery. But it was also recklessness, which imperilled his entire army, and Tacitus turns it into a negative, temeritas. ${ }^{61}$ That quality Germanicus admittedly lacked, and it was no bad thing that he did; it did not make him any the less effective as a general, and he was not a danger to his men. Once again, Tacitus has taken a piece of Curtius' encomium and

superbia and ira, which resulted in the murders of his friends inter epulas. If he had not been submerged in the tidal wave of fortuna, he would have been unsurpassed in continentia and clementia. For Tacitus' bystanders, then, Germanicus has exactly the qualities of the young, uncorrupted Alexander.

${ }^{54}$ Tac. Ann. 2.73.2: sed hunc mitem erga amicos.

55 Clementia is the first of the noble qualities in which Germanicus surpassed Alexander. It is explicitly adduced in his treatment of Piso (erat, ut rettuli, clementior: Ann. 2.57.2), where Tacitus seems to be referring back to the commendation of his mansuetudo, again in relation to Piso, at Ann. 2.55.3. Before that, his clementia only appears in his reception of the Cheruscan noble Segestes (Ann. 1.58.5). Ordinary Germans had a very different experience (see below).

${ }_{56}$ Curt. 10.5.32: modus immodicarum cupiditatum, veneris intra naturale desiderium usus, nec ulla nisi ex permisso voluptas.

${ }^{57}$ Curt. 5.1.36: Nihil urbis eius corruptius moribus, nihil ad inritandas inliciendasque immodicas cupiditates instructius. Here it is quite clear. Immoderate passions are one of the marks of moral corruption.

${ }_{58}$ Curt. 8.3.5: et ad desiderium levandum noctes agere inter paelices coepit.

${ }^{59}$ A figure made notorious by Curtius' narrative $(6.5 .23 ; 10.1 .25-37$; for other references and modern literature, see J. E. Atkinson, A Commentary on Q. Curtius Rufus' Historiae Alexandri Magni Books 5 to 7,2 [Amsterdam, 1994], 196-7).

${ }_{60}$ Ann. 2.73.2: modicum voluptatum, uno matrimonio, certis liberis egisse.

${ }^{61}$ Curtius himself highlights Alexander's temeritas, notably at the Malli town (9.5.1), where it has a very unfavourable connotation. However, it was mitigated by the king's invariable good fortune (3.6.18; 9.9.2; cf. 10.5.35) and was never disastrous. 
inverted it to enhance his picture of Germanicus. Contrast, however, what he does with Alexander's clementia. Curtius highlights his clementia in devictos, and goes on to mention the number of defeated enemies whom he confirmed in their regimes. ${ }^{62}$ This is something that Tacitus does not address in the context of the bystanders' remarks. However, in his own remarks on Germanicus' international popularity he mentions his mansuetudo in hostes (2.72.2). This, as Goodyear and others have noted, ${ }^{63}$ is an outrageous contradiction of his own narrative. Tacitus himself had given a terrifying picture of his massacre of the Marsi, defenceless in a drunken stupor, sparing neither age nor sex, and reported him calling for a final solution of the German problem. ${ }^{64}$ The verdict is extraordinary, without parallel in Dio's obituary note, which simply contrasts Germanicus' bravery against the enemy with his gentle behaviour at home. ${ }^{65}$ I can only assume that Tacitus hijacked Curtius' encomium of Alexander as blatantly as Ptolemy did his body, and simply transferred it to Germanicus. 'Falsehood attends on wishful thinking.' Goodyear is quite justified in this harsh verdict. For Tacitus, the prince had all Alexander's positive qualities in equal or greater measure, and so, facts notwithstanding, he could legitimately be portrayed as a humane conqueror.

I should also direct attention to the curious (and practically unique) ${ }^{66}$ phrase certis liberis, which I have rendered 'with defined progeny'. It is usually translated 'with legitimate children', which suggests that Alexander's posthumous son by Rhoxane was in some way illegitimate. But he had notoriously married Rhoxane according to Macedonian ritual, ${ }^{67}$ and no source suggests that the posthumous Alexander was fathered by anyone other than the king himself. ${ }^{68}$ Goodyear has drawn attention to Curtius' phraseology (at 10.5.12) when describing the reaction to Alexander's demise. The Macedonians felt threatened sine certo regis herede, 'without a defined heir to the king'. Alexander had designated no successor, and there was no guarantee that Rhoxane's unborn child would be male. With him there was no certainty, no security, whereas Germanicus had a plethora of children, male and female. His heirs were clearly defined, as was the succession to his estate. If he had ever assumed the purple, there was no danger of the chaos which had struck the Macedonians because of the undefined succession - though the oversupply of sons did pose a potential problem. Tacitus is probably echoing Curtius, encouraging his readers to think of the problems of sovereignty and succession, and there may be another malicious insinuation of sexual licence at Alexander's court.

${ }^{62}$ Curt. 10.5.28: the reference is to the benefactions to dynasts such as Mazaeus in Babylon or Porus and Abisares in India.

${ }^{63}$ F. R. D. Goodyear, The Annals of Tacitus Books 1-6 (Cambridge, 1972-), 2.415-16. Furneaux believed that the reference was primarily to Germanicus' treatment of captives, while Koestermann simply noted that Germanicus' mansuetudo did not prevent his perpetrating atrocities (in part justified by the treatment of Varus' men).

${ }^{64}$ Tac. Ann. 1.51.1: non sexus, non aetas miserationem attulit; 2.21.2: solam internicionem gentis finem bello fore. For a similar scene in Alexander literature, expressed in similar language, compare Curt. 9.5.20.

${ }^{65}$ Dio 57.19.6: 'while he was the bravest of men with respect to the enemy, he treated his own people with extreme mildness ( $\dot{\eta} \mu \epsilon \hat{\omega} \tau \alpha \tau \alpha)$ '.

${ }^{66}$ Compare Cic. Inv. rhet. 1.2 (the context is primitive society without a code of law): nemo nuptias viderat legitimas, non certos quisquam aspexerat liberos. This is the only direct parallel I can find for Tacitus' terminology.

${ }^{67}$ Curt. 8.4.27 (cf. M. Renard and J. Servais, 'À propos du mariage d'Alexandre et de Roxane', $A C 24$ [1955], 29-50). Other sources stress that the union was a marriage in proper form (Arr. 4.19.5; Plut. Alex. 47.7-8; Mor. 332E).

${ }^{68}$ In contrast, Philinna, the mother of Philip III, was alleged to have been the concubine, rather than the wife, of Philip II (Athen. 13.578A; cf. Just. 9.8.2; 13.2.11). 
The necrology on Alexander may have had its effect on the most celebrated necrology of them all, in the remarks that Tacitus places in the mouths of the bystanders at Augustus' funeral. ${ }^{69}$ When the historian expounds the comments of the prudentes, the first item is a tribute to Augustus' dutifulness to his adoptive father: it was this, along with the political crisis in the state, that drove him to civil war. The phrase also occurs as the first item in the adverse comments: his dutifulness was a sham, adopted for propaganda purposes. ${ }^{70}$ Now, the phrase pietas erga parentem may seem trite and superficial, and Cicero twice defines pietas as the fulfilment of one's duty to parents. ${ }^{71}$ However, it occurs with surprising infrequency in later literature, outside Tacitus only once, in Curtius' necrology for Alexander (10.5.30), where he emphasizes the king's pietas erga parentes, manifest in his decision to deify Olympias and the avenging of his father's death. ${ }^{72}$ The more charitable of Tacitus' prudentes also emphasize the vengeance taken upon Caesar's assassins, only to be undercut by the critical observation that it is proper to remit private enmities in the public interest. ${ }^{73}$ Here there may well be an additional implication that Augustus, who - to some degree at least - saw Alexander as a model, fell short of his exemplar. Alexander had no motive but filial duty in avenging his father, ${ }^{74}$ and his vengeance did not lead to civil war. The verbal echo here adds force to the negative remarks of the observers at Augustus' funeral, and undermines the favourable comments from the very outset.

We may revert to Tacitus' comparison between Germanicus and Alexander. The necrology is not the final play on Curtius' narrative of Alexander's death. It is evoked in the celebrated scene in which Germanicus' ashes are laid to rest in the mausoleum of Augustus. Tacitus' description (Ann. 3.4.1) is highly wrought: that day was marked by contrasts of moods - now it was desolate in silence, now disquieted by lamentations (modo per silentium vastus, modo ploratibus inquies). This is a striking echo of Curtius' first words after Alexander's death: at first, the entire palace resounded with weeping and lamentation; presently it all lapsed mute in sorrowful silence, as though in a wilderness of desolation. ${ }^{75}$ Here we have precisely the same contrast that we find in Tacitus, exactly the same coupling of noisy lamentation and desolate silence, and the vocabulary is mirrored. ${ }^{76}$ Tacitus is terser and his rhetoric

${ }^{69}$ I owe this parallel to A. J. Woodman.

${ }^{70}$ Tac. Ann. 1.9.3: hi pietate erga parentem et necessitudine reipublicae... ad arma civilia actum; Ann. 1.10.1: pietatem erga parentem et tempora rei publicae obtentui sumpta. Compare Ann. 16.30.2, where Tacitus emphasizes the pietas of Servilia, imperilled by caritas erga parentem, a contrast, perhaps deliberate, with the very disingenuous pietas of Augustus.

${ }^{71}$ Cic. Inv. 2.66: pietatem quae erga patriam aut parentes aut aliquos sanguine coniunctos officium conservare moneat. Cf. Part. Or. 78.

${ }_{72}$ Curt. 10.5.30: iam pietas erga parentes, quorum Olympiada immortalitati consecrare decreverat, Philippum ultus erat. On the consecration of Olympias, see Curt. 9.6.26.

${ }^{73}$ Tac. Ann. 1.9.4: dum interfectores patris ulcisceretur; 1.10.3: quamquam fas sit privata odia publicis utilitatibus remittere.

${ }^{74}$ The first two books of Curtius' history are lost, and we have no means of judging how he dealt with the punishment of the supposed murderers of Philip; but there is no defensive qualification in the necrology, and it looks as though Curtius thought that there was a genuine conspiracy and that its members were properly punished.

${ }^{75}$ Curt. 10.5.7: Ac primo ploratu lamentisque et planctibus tota regia personabat; mox velut in vasta solitudine omnia tristi silentio muta torpebant.

${ }^{76}$ The combination of vastus and silentium, favoured by Tacitus (Agr. 38.2; Hist. 3.13; Ann. 4.50.4), is found elsewhere in Livy (10.34.6), but we do not have the contrast with lamentation which is so effective in Curtius and Tacitus. 
more daring, ${ }^{77}$ but it is clear that he is echoing and outdoing one of the more ambitious passages of Curtius. And the echo of course invites the comparison with Alexander. The reader is attuned to recall the wording of Curtius, and the parallel between Germanicus and Alexander is made subliminally. There is no need for it to become explicit in the text.

The same applies to the famous passage on Germanicus' visit to Egypt. Curtius had emphasized Alexander's desire to penetrate Egypt as far as the celebrated palaces of Memnon and Tithonus, but adds that he abandoned the scheme because of the imminent war. ${ }^{78}$ Germanicus, however, went up the Nile as far as Elephantine and Syene, attending the famous dawn performance of the statue of Memnon. Tacitus does not explicitly mention the precedent of Alexander, but he introduces the episode with the emphatic statement that he travelled to Egypt cognoscendae antiquitatis. This exactly mirrors Curtius' description of Alexander (cognoscendae vetustatis avidum), and can hardly be coincidental. ${ }^{79}$ Germanicus' antiquarian curiosity in entering Egypt inevitably evoked the figure of Alexander, and the strong echo of Curtius at the beginning of the section must be a cue to alert the reader. What is more, the context in Curtius suggests a further, more subtle insinuation. Germanicus is compared with Alexander, and did what Alexander failed to do. But, as Curtius emphasizes, Alexander deliberately renounced the sight seeing because he had more urgent business with Darius. That invites the reader to reflect that, had Germanicus followed his example, Piso would have had less opportunity to countermand his ordinances (Ann. 2.69.1), and the final, fatal breach might not have occurred. This may be one of the few implicit blemishes in Tacitus' picture. For all his brilliance, Germanicus was prone to errors of judgement. ${ }^{80}$ The prince may have eclipsed Alexander in clementia and temperantia, but he lagged far behind him (and Tiberius) in sollertia. ${ }^{81}$

The implicit contrast may have occurred somewhat earlier in the saga of

77 In their commentary (95), Woodman and Martin draw attention to the transference of vastus from silentium to dies (where it is unparalleled), the non-personal use of inquies, and the forceful ploratus.

${ }^{78}$ Curt. 4.8.3-4. The episode does not appear in any other extant source, but there is no reason to discount it. Alexander was deeply interested in the course of the Nile and the phenomenon of its flooding (cf. A. B. Bosworth, A Historical Commenary on Arrian's History of Alexander 2 [Oxford, 1995], 272-3, and in TOPOI 3.2 (1993) = M.-F. Boussec and J.-F. Salles [edd.], Athens, Aden, Arikamedu [New Delhi, 1995], 27-44), and it is likely enough that he wished to explore its upper reaches.

79 'T. seems closely to echo Curtius. That may reveal something about his view of Germanicus' (Goodyear [n. 63], 2.373, n. 1). Contrast Atkinson (n. 14), 364: 'The verbal similarity was no doubt coincidental'. That is unlikely. In the whole of Latin literature there is no other parallel for the combination of either vetustas or antiquitas with the gerundive cognoscendus. In Curtius the gerundive is an objective genitive, dependent on avidum (rare enough in itself: outside Curtius and Tacitus only found in Sallust [Jug. 35.3]), which Tacitus has varied with a characteristic genitive of purpose.

${ }^{80}$ Cf. Ann. 2.8.2, a celebrated crux, but the one thing clear about it is that Germanicus is stated to have made a mistake. At Ann. 1.78.2 the concessions to the German legions are represented as male consulta. Whether Tacitus is speaking in his own right or representing Tiberius' perspective (cf. 1.52.1), the tone is strongly negative. So Goodyear (n. 63), 2.178; C. Pelling, in A. J. Woodman and T. J. Luce (edd.), Tacitus and the Tacitean Tradition (Princeton, 1993), 64, observes that Tacitus consciously keeps his opinion divorced from the narrative. True, but there is a rich sub-text of allusion and insinuation.

${ }^{81}$ Cf. Curt. 10.5.31: consilium par magnitudini animi et, quantam vix poterat aetas eius capere, sollertia. The terminology echoes famous passages of Cicero (Mil. 1; cf. Quint. 11.3.49; Phil. 11.28) and Sallust (C. 54.1), but Curtius compares mental qualities, not, as is the case elsewhere, individuals (cf. BAlex. 15.2). 
Germanicus. In his great speech to the mutinous troops he builds up to a climax of reprobation (Ann. 1.42.3). He denounces them for repudiating the emperor who had led them to victory, and, with heavy sarcasm, the prince adds: 'excellent thanks you are returning your commander' (egregiam duci vestro gratiam refertis). This, one would think, was a standard topos, a regular rhetorical figure. In fact, apart from one instance in the Pseudo-Quintilian Declamationes, ${ }^{82}$ the only parallel is in Curtius. ${ }^{83}$ Here the speaker is not, as we would expect, Alexander haranguing his troops at Opis. ${ }^{84}$ It is the page and would-be regicide, Hermolaus, who begins his defence by listing the nobles who had died at Alexander's hands and continues with exactly the same sarcastic interjection: Quibus tu egregiam gratiam rettulisti (8.7.4). If, as seems highly probable, the two passages are linked, Germanicus is engaged in an implicit critique of Alexander, whose murderous qualities are replicated in the German legions. Like Hermolaus, he defends traditional values, the military values of obsequium and disciplina, but, unlike Hermolaus, he succeeds by salutary blood letting. Here the negative image of Alexander assumes its darkest colours.

Another echo is to be found in the account of the Pannonian mutiny, where Drusus exploits the changed mood of his troops, cowed by the lunar eclipse. He considers that he should take advantage of the alteration (utendum inclinatione Caesar . . ratus) ${ }^{85}$ and effectively puts an end to the mutiny. The wording is exactly mirrored in Curtius' account of an equally famous eclipse, that which occurred before Gaugamela. Then there was similar consternation in the Macedonian camp, which was turned to elation by the interpretation of the lunar eclipse as a portent of disaster for the Persians. ${ }^{86}$ Alexander too decides to exploit the mood of the moment (rex impetu animorum utendum ratus). Goodyear noted the parallels of language and context, ${ }^{87}$ but he did not realize the extreme infrequency of the combination of the participle and gerund: utendum and ratus only occur together in Curtius and Tacitus. This makes it almost certain that there is a conscious echo in Tacitus. Drusus, like Alexander, takes advantage of the superstitions of his men, and the result is the timely end to the Pannonian mutiny. It is a less glorious outcome than the crowning victory of Gaugamela, but there is still something of Alexander in Drusus, who suppresses the mutiny with more promptitude and less bloodshed than the more histrionic Germanicus.

There can now be little doubt about the most famous echo in Tacitus. In one of Curtius' most powerful and effective speeches (7.1.18-40) the Macedonian general Amyntas, son of Andromenes, defends himself against the charge of complicity with

${ }^{82}$ Decl. 310.12: Egregiam, hercules, gratiam viris fortissimis reddimus.

${ }^{83}$ The parallel (though not its uniqueness) was noted by G. B. A. Fletcher, Annotations on Tacitus, Coll. Latomus 71 (Brussels and Berchem, 1964), 11 and Goodyear (n. 63), 1.292.

${ }^{84}$ There Alexander does indeed reproach his troops for ingratitude (Curt. 10.2.28): ingratissimi cives. This picks up a motif in Germanicus' speech (Ann. 2.42.2: an cives), but there is no direct verbal echo.

${ }^{85}$ Tac. Ann. 1.28.3. The expression is repeated at Ann. 14.23.1, where Corbulo exploits the terror caused by his destruction of Artaxata (utendum recenti terrore ratus) to occupy Tigranocerta. The terror of the Armenians neatly parallels the superstitious panic of Drusus' troops, and the triumphant Corbulo is given a tinge of colour from the palette of Alexander.

${ }^{86}$ Curt. 4.10.2-8. On the lunar eclipse see Arr. 3.7.6; Plut. Alex. 31.8; A. Sachs and H. Hunger, Astronomical Diaries and Related Texts from Babylonia, Denkschr. Oest. Ak. d. Wiss. 195 (Vienna, 1988), 1.179 (cf. G. F. Del Monte, Testi dalla Babilonia Ellenistica i [Pisa and Rome, 1997], 1-5). The interpretation is unique to Curtius, but recalls Herodotus (7.37.3).

87 Goodyear (n. 63), 1.232, remarking on the similarity of context. I am grateful to Jane Bellemore for drawing the passage to my attention. 
the disgraced Philotas. In the course of his speech he refuses to deny his friendship with Philotas, on the ground that everyone at court (from the king down) wished for the friendship and solicited his favour. That is reminiscent of the speech which Tacitus (Ann. 6.8) places in the mouth of the Roman eques, M. Terentius, who was indicted during the purge which followed the execution of Seianus. He makes exactly the same defence as Amyntas, pointing out the universal stampede to acquire the friendship of the favourite, the princeps' colleague and son-in-law. In such a situation friendship is no proof of complicity. There is no question that Tacitus accurately represents the gist of the speech, which is independently and briefly reported by Dio. ${ }^{88}$ The similarity of the rhetoric has suggested the conclusion that Curtius was deliberately injecting Roman color into his speech and including material from contemporary historians whom Tacitus also used.$^{89}$ But the verbal echoes suggest a much closer relationship. Some are listed in tabular fashion by Atkinson. The two speakers admit their friendship with the dead favourites in strikingly similar language, ${ }^{90}$ The shaping, and much of the vocabulary, is the same, and the thought is closely parallel. However, the most significant correspondence occurs in a seemingly casual and unemphatic phrase. At the penultimate climax of his speech (7.1.37) Amyntas declares that, however things turn out (utcumque cessura res est), he would prefer Alexander to be displeased by his presentation, not his case. For all its mundane appearance, the qualification only recurs once in Latin literature, precisely in Tacitus' rendering of the speech of Terentius (Ann. 6.8.1): however things turn out (utcumque casura res est), he will continue to admit his friendship with Seianus. Apart from a slight variation of the wording, the patterning is exact, and it is unique. It can hardly be coincidental, and again it must be Tacitus who borrows from Curtius. And the borrowing enhances his narrative. Terentius takes on the colour of Amyntas, pleading his case before the army assembly, and there is a secondary parallel between Philotas and Seianus. Both were favourites brought low by the guile of their rulers. Curtius suggests that Philotas was convicted of conspiracy on suspect evidence, ${ }^{91}$ the victim of Alexander's sollertia, which was matched and surpassed by Tiberius. It might not be rash to suggest that the analogy had been developed earlier in the lost part of Book 5 of the Annals. It would allow a rich harvest of intertextual allusion. Curtius may indeed have been influenced by the defence of Terentius, but it is equally possible that the Alexander tradition had already emphasized the universal friendship that Philotas had enjoyed. What seems clear is

${ }^{88}$ Dio 58.19.3-4: 'As for Terentius, he was spared because, when on trial for his friendship with Sejanus he not only did not deny it, but even affirmed that he had shown the greatest zeal on his behalf and had paid court to him for the reason that the minister had been so highly honoured by Tiberius himself.'

89 Atkinson (n. 14), 37 suggests Aufidius Bassus (repeated in ANRW II 34.4 [1998], 3452). He is more undecided in his actual commentary on the speech (Atkinson [n. 59], 251-2). See also G.V. Sumner, 'Curtius Rufus and the Historiae Alexandri', AUMLA 15 (1961), 30-9, esp. 34-5; Baynham (n. 44), 52, 215. A. M. Devine, 'The Parthi, the tyranny of Tiberius and the date of Q. Curtius Rufus', Phoenix 33 (1979), 142-59, esp. 152, argues that Curtius anticipated and influenced Tacitus ('it is distinctly possible, even probable, that Tacitus read and was influenced by Curtius').

${ }^{90}$ Curt. 7.1.26: amicitiam quae nobis cum Philota fuit, adeo non eo infitias, ut expetisse quoque nos magnosque ex ea fructus percepisse confitear. Tac. Ann. 6.8.1: fatebor et fuisse me Seiano amicum et ut essem expetisse et postquam adeptus eram laetatus. The parallel shaping is very clear, and the occurrence of expetisse in indirect speech is very rare (I can only find Cic. Har. Resp. 26 and Val. Max. 8.2.3).

91 For Alexander's disingenuous behaviour, see 6.7.35, 8.16 (Alexander dines with Philotas and converses affably with the man whom he had condemned), 8.24 (stage management of trial); see also 11.39 on the dangers of invidia. 
that Tacitus drew on his account of Amyntas to add colour and astringency to Terentius' defence.

We may now draw some conclusions. First of all, it is evident that the impact and popularity of Curtius' work has been greatly underestimated. Tacitus' allusions are so subtle and occasionally recondite that they can only have been appreciated by a readership steeped in his History of Alexander. They would pick up the verbal tags and react instinctively to them, much as a contemporary readership might react to borrowings from The Lord of the Rings or, in a visual context, to Spielberg's numerous allusions to previous films, many of them distinctively B-grade. The cultured Roman élite would have been more sensitive to rhetorical borrowings than their modern counterparts, but even so, for Tacitus' allusions to have had their full effect they would have had to be thoroughly steeped in Curtius. The greater their familiarity, the more they would have appreciated Tacitus' cleverness. All this does not help us much with the desperate problem of Curtius' date. His work was in circulation and clearly well known by the time Tacitus wrote his Agricola, that is, the time around the death of Nerva (January 98). That is merely a terminus ante quem. I think that the borrowings definitely exclude an identification with the novus homo of the Julio-Claudian period. Tacitus' well-known obituary ${ }^{92}$ gives no hint of any literary pursuits, let alone literary achievement, which is strange if he made such play with the biography of Alexander. On the other hand, my own suggestion that Curtius wrote at the time of Trajan's adoption (late 97) is weakened. ${ }^{93}$ We should have to assume that the work was an immediate bestseller, and had impressed the cultured circle at Rome by the time Tacitus composed the Agricola; and it retained its popularity into the later years of Trajan, when he was writing the Annales. Perhaps the Vespasianic dating is the most likely. ${ }^{94}$ In that case, Curtius had established himself as a modern classic by the time Tacitus began his historical writing, and he retained his status into the second century A.D. (and perhaps even later). There is a striking allusion in Orosius, which looks as though it comes directly from Curtius, not through the intermediacy of Tacitus. ${ }^{95}$

${ }^{92}$ Tac. Ann. 11.21. See the detailed discussion in Atkinson (n. 14), 50-7, arguing for the identification. Compare, however, Tacitus' comment on Pomponius Secundus (Ann. 12.28.2): his triumphal ornaments were less regarded by posterity than his poetry. And the death of Servilius Nonianus is mentioned primarily because of his historical eminence (Ann. 14.19).

${ }_{93}$ 'History and rhetoric in Curtius Rufus', CPh 78 (1983), 150-61, esp. 151-4. Curtius' rhetoric, implying that the new emperor's proclamation resulted in sudden tranquillity (subita serenitate), is just compatible with Vespasian's elevation; his declaration against Vitellius would be represented as the decisive moment of the war, leading to a rapid termination of hostilities. The process may in reality have taken six months, but in the language of flattery that could be contracted to a moment.

${ }^{94}$ See note below. Vespasian has been relatively favoured in recent years. See J. E. Atkinson's review: 'Q. Curtius Rufus' "Historiae Alexandri Magni", ' ANRW II 34.4 (1998), 3454-5, with J. Fugmann, 'Zum Problem der Datierung der 'Historiae Alexandri Magni' des Curtius Rufus', Hermes 123 (1995), 233-43 and Baynham (n. 44), 213-14, 219.

${ }_{95}$ Oros. Hist. ad pag. 7.9.1: anno ab urbe condita DCCCXXV, brevi illa quidem sed turbida tyrannorum tempestate discussa, tranquilla sub Vespasiano duce serenitas rediit. This bears a remarkable similarity to Curt. 10.9.3: quantam tempestatem subita serenitate discussit. Orosius expands and weakens the model, but he echoes the unique triplet tempestas, serenitas, discutere. Now, Orosius knows and quotes Tacitus' Historiae (cf. T. D. Barnes, 'The fragments of Tacitus' "Histories"', CPh 72 [1977], 224-31), but he can hardly be doing so in this instance. There is no echo of Curtius' rhetoric in Tacitus' account of the elevation of Vespasian, and the sentiment directly contradicts his own view that the death of Vitellius did not produce a lasting peace (Hist. 4.1.1: bellum magis desierat quam pax coeperat). The allusion can hardly be to the lost books of the Annales, for Orosius nowhere betrays knowledge of any Tacitean work other than the 
What emerges most impressively from the investigation is the sheer sophistication of Tacitus' method. No scissors and paste for him. He has portions of Curtius at his fingertips, the speeches especially, and he strengthens and sharpens their rhetorical content. The context is always significant, and the allusions to the world of Alexander add depth and colour to Tacitus' history of his world. The immoderately moderate Agricola becomes an Alexander without temeritas, while the malevolent, secretive Domitian has all the ruthlessness and duplicity of the Macedonian without his redeeming courage and strategic virtuosity. Underneath the annals of the Roman aristocracy there are echoes of Alexander's character and court, a continuous counterpoint of allusion, which supplements, enriches, and modifies the historical narrative, setting it against a different but comparable context. Curtius is clearly only one of a multiplicity of literary foils, and we are lucky to have his work for comparison. Most of the other literature of the period, the popular literature in particular, has totally vanished, and we have no inkling of the range of authors with whom Tacitus interacted. However, if his use of Curtius is any guide, it was large, and the subtextual interplay was rich and intensely suggestive. Underneath the surface of the historical narrative there may be a veritable iceberg of implicit commentary.

University of Western Australia

A. B. BOSWORTH

abboswor@cyllene.uwa.edu.au

Historiae (Barnes, 229). It looks as though Curtius' eulogy of the new emperor was familiar to Orosius and evoked by him in the context of Vespasian's accession. If so, there is a prima facie case that he thought that the eulogy referred to Vespasian and that Curtius elsewhere indicated that Vespasian was the reigning emperor. Cf. Fugmann (n. 94), 237-9, following J. Schmid, 'Zur Frage über das Zeitalter des Q. Curtius Rufus', NJPhP 113 (1876), 704. To avoid this conclusion we should have to assume that Curtius and Orosius independently echoed a lost passage of Livy, who was fond of the contrast between storm and calm (cf. Livy 26.11.3; 30.38.11 [subita serenitate]). However, the remarkable triple echo makes it more likely that Orosius' inspiration was Curtius himself, who in his turn echoed Livy. 
Reproduced with permission of the copyright owner. Further reproduction prohibited without permission. 